\title{
Exploring Factors that Predict STEM Persistence at a Large, Public Research University
}

\author{
Mario I. Suárez ${ }^{1}$, Alan R. Dabney ${ }^{2}$, Hersh C. Waxman ${ }^{3}$, Timothy P. Scott ${ }^{4}$ \& Adrienne O. Bentz \\ ${ }^{1}$ School of Teacher Education and Leadership, Utah State University, Logan, UT, USA \\ ${ }^{2}$ Department of Statistics, Texas A\&M University, College Station, TX, USA \\ ${ }^{3}$ Department of Teaching, Learning, and Culture, Texas A\&M University, College Station, TX, USA \\ ${ }^{4}$ Office of Student Success, Texas A\&M University, College Station, TX, USA \\ Correspondence: Mario I. Suárez, School of Teacher Education and Leadership, Utah State University, 2805 Old Main \\ Hill, Logan, UT, USA.
}

Received: January 13, 2021

Accepted: February 20, 2021

Online Published: February 24, 2021

doi:10.5430/ijhe.v10n4p161

URL:https://doi.org/10.5430/ijhe.v10n4p161

\begin{abstract}
The present study explores demographics, pre-university characteristics and multi-year (2003-2013) tracking of a census of 53,077 students who initially declared a STEM major upon entering a research university in the United States Southwest and seeks to predict graduation with a STEM and non-STEM degree. Guided by QuantCrit theory, we use multilevel models to determine factors that predicted persistence in any major and factors that predicted persistence in STEM. We also use marginal effects to explore the intersection of ethnicity, gender, and first-generation status. Results highlight the disparity that exist amongst Black students and their White counterparts with regards to persistence in any major. We also highlight the gap between first-generation White and Black first-generation females and their Asian and International counterparts with regards to persistence in STEM. Implications for future research and practitioners suggest further attention needs to be paid to Black first-generation students in STEM.
\end{abstract}

Keywords: STEM, persistence, multilevel modeling, intersectionality, QuantCrit, first-generation students

\section{Introduction}

It has been over a decade after the initial Rising Above the Gathering Storm (2007) report, which initially raised questions about the future of the United States (US) science, technology, engineering, and mathematics (STEM) fields, and the fields are still struggling to figure out how to meet the needs of a diverse society by recruiting our nation's brightest minds (OCGA, 2019). This report, authored by the National Academies of Medicine, Engineering and Science, described the critical role of STEM in the global economy and the shrinking number of university graduates in these fields. Only about $16 \%$ of undergraduates in the US chose STEM as a career major, compared to higher percentages for other countries (up to $47 \%$ in China), which can not only be detrimental to the US economy, but to the global market (National Science Board, 2010). Given the variation in educational constraints with different countries around the world, this statistic still warrants attention, considering that the number of STEM occupations in the US is projected to increase by $8 \%$ by 2029 (US Bureau of Labor Statistics, 2020), which can have an effect on how other countries promote STEM in their institutions of higher education.

Presidents in the US since then have attempted to increase the recruitment and retention of minoritized and non-minoritized populations into STEM through the passage of legislation such as The America COMPETES Act, signed into law by then President George W. Bush in 2007. These attempts made little, if any, difference, as a later report in 2010 by the National Academies, Rising Above the Gathering Storm, Revisited: Rapidly Approaching Category 5, addressed the same issue with even more urgency. A report to President Obama, Engage to Excel (2012), estimated the need for 1 million additional STEM professionals, emphasizing the need for a diverse STEM workforce. A report by the National Academy of Sciences, Barriers and Opportunities for 2-Year and 4-Year STEM Degrees (2016), stated that in the pursuit of a STEM higher education, all undergraduates who are "interested in a STEM credential should be afforded the opportunity to earn the credential they seek with a minimum of obstacles" (p.8). To meet this need, undergraduate STEM degree attainment must be increased, keeping in mind the systemic barriers many universities place on minoritized students, which are not always easily measurable. 
The purpose of the present study is to explore factors that predict persistence for minoritized students at a predominantly White institution (PWI), and explore the intersection of ethnicity, gender, and first-generation status, using pre-existing data from 2003-2013 on entering STEM majors at a large public research university in the Southwestern region of the US. Though this study focuses on one university in the US, it has implications for international students who seek to study in the US, as this university attracts a large number of international applicants. The study explores demographics, pre-university characteristics, and multi-year tracking of student data, seeking to answer the following questions:

1. Do student demographics and characteristics predict graduation from any major or a STEM major for students who initially declare a STEM major?

2. How does the intersection of race, gender, and first-generation status interact to predict graduation from any major and a STEM major for students who initially declare a STEM major?

\section{Material Studied}

In order to better understand the factors that predict STEM persistence for Black, Indigenous and People of Color (BIPOC) students in relation to their White counterparts, we conducted a literature review of relevant topics. First, we review the challenges and successes of females in STEM. We then explore literature on BIPOC students at PWIs, including first-generation students. Finally, we explore research on relationships between standardized test scores and persistence.

\subsection{Females in STEM}

While the percentage of women in science has risen since the 1990s, that percentage is greater when including social sciences. Women are still underrepresented in fields such as engineering, physics, computer science, economics, and post-baccalaureate or graduate mathematics degrees (National Academy of Sciences, 2016; National Science Foundation, 2017). Depending on the sample used, some findings show positive and negative outcomes for women. For example, some work shows that women in STEM majors are more likely to persist if there are more female students in the program and that they are more likely to enter the university not intending to declare a STEM major (Griffith, 2010), and that women in the physical sciences, computer sciences, mathematics, and engineering majors were more likely to persist than those in health sciences and psychology, and non-science and engineering majors defined by the National Science Foundation (NSF; George-Jackson, 2014). However, other studies have found no significant differences in the persistence of men and women in STEM (King, 2016). Moreover, Williams, Phillips, and Hall (2016) attributed discrimination toward women in STEM to traditional gender roles, such as motherhood and masculine-like behaviors (e.g., assertiveness). The undervaluing of women in society could have an effect on the persistence of women in STEM, as men make approximately $22 \%$ more in salary than women after graduation (Xu, 2015).

Research has shown that the experiences of BIPOC women in STEM are quite different than their White counterparts in terms of interaction with resources and sense of belonging. For instance, Espinosa (2011) found that BIPOC women engage more than their White counterparts in collaborative activities like peer discussion and research programs in spite of the challenges they encounter. One of these challenges is the lack of sense of belonging within their programs and within the STEM field. That is, BIPOC women more often tend to report having experienced hostile, racist, and sexist working environments in STEM (Castellanos, 2018; Chaleston et al., 2014; Reyes, 2011). Another challenge, particularly for Latinas, is the effect of income and generational status, as women with higher income were more likely to exhibit positive outcomes in STEM (Castellanos, 2018).

\subsection{BIPOC Students in STEM and First-Generation Status}

The literature is replete with examples of BIPOC students who are not retained in STEM majors for various reasons (Flynn, 2016; George-Jackson, 2014; Hurtado et al., 2009; Hurtado et al., 2011; Hurtado et al., 2015; Johnson, 2012; Reyes, 2011). Some researchers have tried to understand demographic factors that have historically kept BIPOC and first-generation students away from STEM programs of study (Crisp, Nora, \& Taggart, 2009; Crisp \& Nora, 2010; Fleming, 2002; Flynn, 2016; Guiffrida \& Douthit, 2010). For example, Crisp, Nora, and Taggart (2009) found that students' ethnicity, gender, SAT mathematics score, and GPA, all significantly predicted STEM persistence for BIPOC students. A later study by Crisp and Nora (2010) of Latinx students in 2-year and 4-year universities found that financial aid status also impacted persistence early on in their programs, an effect that dissipated by year 3 .

Aside from demographic factors, research has also addressed sociocultural and systemic inequalities that impact STEM persistence, which are more difficult to measure statistically. For instance, Trenor and colleagues (2008) explored the experiences of BIPOC women engineering students through two case studies, and found that social 
capital, manifested via family support, played a major role in their participants persistence. This finding was later supported by Garriott and colleagues (2017), who explored first-generation students' persistence in engineering. That is, greater levels of familial support produced better outcomes that contributed to student persistence.

\subsection{Standardized Test Scores and Achievement}

While early research relied heavily on standardized test scores (SAT) to determine positive outcomes in graduation (Burton \& Ramist, 2001; Fleming, 2002; Moffat, 1993), those tests have since then been disputed in numerous studies because they do not necessarily correlate with achievement at the university (Fleming \& Morning, 1998). Particularly, early research showed that SAT results predicted a small percentage of a students' grade point average (GPA) in their first years at the university (Naumann, Bandalos, \& Gutkin, 2003) and that high school grades more effectively predicted graduation (Scott et al., 2011). Thus, for this study, we use high school grade point average, which is the equivalent of secondary schools in other countries, as a covariate in addition to standardized test scores.

Standardized test scores have also shown to highlight disparities based on class and racial identity. For example, Everson and Millsap (2004) showed that socioeconomic status may play a role in test results, as did Rothstein (2004). Fleming and Garcia (1998) studied the tests' predictive ability with African American students at Black and White university and found slightly higher predictability for Black students at predominantly Black schools, compared to Black students at predominantly White schools. Scott and colleagues (2011) suggested disaggregating data based on gender, ethnicity, socioeconomic status, etc., and where possible, longitudinal tracking of students and larger datasets. Since standardized entrance exam results continue to be used as a means to determine academic success at universities across the US, we use this data in tandem with other factors that may impact student persistence in STEM.

\section{Methods}

This study differs from others in that our sample is a census of students who initially declared a STEM major upon entering this particular university in the Southwest region of the US. For comparison, the latest data as of Fall of 2019 for this large, public research institution reflect that about 53\% of the population is male, about $54 \%$ White, about $22 \%$ Latinx, about 8\% Asian, about 9\% International, and about 3\% Black. The remainder of the ethnic groups consist of multi-racial students, Native Hawaiian or Pacific Islanders, or were not reported. About $20 \%$ of the overall degree-seeking student population identify as first-generation university students.

\subsection{Theoretical Framing}

\subsubsection{QuantCrit Theory}

This analytical lens for this study is guided by quantitative critical research theory, or QuantCrit, (Gillborn, Warmington, \& Demack, 2018) as an alternative to help quantitative researchers better understand inherent subjectivities in quantitative research. As a way to understand intersections of race, class, gender, and others through statistics in a more critical manner, QuantCrit is introduced as a theory of statistics that is based on five principles. According to Gillborn et al. (2018), racism and White supremacy is central to statistical research, which does not imply that statisticians are necessarily racist. It means that in statistics, race and ethnicity, as socially constructed categories, can often be used to reproduce racial stereotypes through nationalistic views. Moreover, numbers should not necessarily be presented as a neutral way of representing said group(s), as these statistics are interpreted and created by individuals who are influenced by their own philosophical worldview. Third, for Gillborn et al. (2018), there is nothing natural about categories given that they are based off of historically racist assumptions. Fourth, QuantCrit rejects the notion that methodologists can truly be objective, thus, the numbers do not speak for themselves. Finally, Gillborn et al. suggest that we as researchers studying inequality must embrace subjectivity by to work towards social justice and equity of underrepresented populations. Together, these five principles provide a lens through which to better understand the lack of diversity in STEM, and thus, further disaggregate the data to look at intersections of race, class, and gender.

\subsection{Analytical Sample}

The data consist of a census of 53,077 students who initially declared a STEM major upon entering the university. The university's Institutional Review Board approved all secondary data analyses concerned with this study. Data were extracted from 2003-2013 from the university's internal database and include fall, spring, and summer semester academic history such as major declared and grade point average by semester and follows each student in their specific cohort until completion or dropout from the university. Though the data was not recent, the authors chose a decade to focus on for this study, as demographics for this particular university have not changed drastically in several decades, especially for Black students. Thus, we selected seven freshmen cohorts to focus on and follow until their targeted completion. In order to identify all possible students who initially declared a STEM major, we decided to use the 
Department of Homeland Security (2016) and the National Science Foundation (2014) lists of approved/designated STEM fields, similar to George-Jackson (2014).

\subsection{Variables}

Dependent variables used in the analyses are graduation from any major, represented by a dichotomous variable $(0=$ No, $1=$ Yes $)$, and stemdegree, also a dichotomous variable $(0=\mathrm{No}, 1=\mathrm{Yes})$, to predict whether the student graduated with a STEM degree. Independent variables consist of the total number of semesters (numeric variable), ethnicity (categorical variable where 1=Black only, $2=$ Latinx only, $3=$ Asian only, $4=$ International, $5=$ White, and $6=$ Other), first-generation status $(0=\mathrm{No}, 1=\mathrm{Yes})$, socioeconomic status denoted by Pell-eligibility $(0=\mathrm{No}, 1=\mathrm{Yes})$, gender $(0=$ Male, $1=$ Female $)$, transfer student status $(0=$ Not a transfer student, $1=$ Transfer student $)$, ACT scores for critical reading and mathematics (numeric variables), SAT scores for critical reading and mathematics (numeric variables), cumulative GPA (numeric), high school ranking (numeric), and high school class size (numeric). Table 1 displays all descriptive statistics for variables used in the analysis. Additionally, since not all students took both the SAT and the ACT standardized exams, concordance tables were utilized for conversions (College Board, 2016) as Long and Tienda (2010) have done. We report findings with SAT converted scores, as there were no differences in the results between the two. Additionally, we note in the US, Pell-eligibility is a measure of socioeconomic status. That is, students that come from families with lower socio-economic status tend to be eligible for Pell grants, which are federally funded grants.

\subsection{Data Analysis}

To account for cohort effects, given that there was a recessionary period in the range of time (2003-2013) of available data, we use multilevel logistic regression models with cohort fixed-effects. Since we use QuantCrit as a guiding framework, we use methods similar to López et al. (2018), who in addition to multilevel logistic regression models in their examination of the intersection of race, class, gender, and social location, they go a step further and include linear combinations of marginal effects, which provide a deeper look into each of 20 different groups in the study which would otherwise be collapsed for regression analysis. Using marginal effects provided for the analysis of the interactions between the different race, class, and gender categories of the participants in the study, which in their case, highlighted disparities in the graduation rates of low-income, American Indian men and high-income, White women, for example. Likelihood ratio test statistics and residual intraclass correlations are reported for model fit, as López et al. (2018) recommend. All data was analyzed using Stata 16 software (StataCorp 2019).

Numeric and categorical variables are interpreted in the same manner, respectively, throughout this paper. For numeric variables, we interpret each odds ratio as the odds of either graduating with any major or with a STEM major for each unit increase in the independent variable, holding all else equal. For categorical variables, each odds ratio represents the odds of either graduating with any major or with a STEM major for the particular independent variable compared to the reference group in brackets, holding all else equal.

\section{Results}

Table 1 displays the descriptive characteristics of the students in the sample who initially declared a STEM major. The sample, compared to the university, is majority female (50.54\%), White (73.96\%), over three-quarters non-transfer students $(75.5 \%)$, not first generation $(92.57 \%)$, and not Pell-eligible $(91.79 \%)$. The students in the sample have a slightly higher SAT critical reading score than mathematics score, have a mean cumulative grade point average (GPA) of almost 3 , and a mean total number of semesters of about seven. 
Table 1. Descriptive characteristics of students declaring initial STEM major, 2003-2013 (N=53,077)

\begin{tabular}{lccc}
\hline Variable & M (SD) / $~$ & Min & Max \\
\hline Number of semesters & $7.0317(3.1224)$ & 1 & 21 \\
Cumulative GPA & $2.9578(0.7099)$ & 0 & 4 \\
HS rank & $67.9393(84.4631)$ & 0 & 5000 \\
HS class size & $446.9824(245.7889)$ & 0 & 9541 \\
SAT score & & & \\
Mathematics & $658.8298(197.9638)$ & 200 & 1600 \\
Critical reading & $632.7423(213.6140)$ & 200 & 1600 \\
$\%$ First-generation & 7.43 & - & - \\
$\%$ Pell-eligible & 8.21 & - & - \\
$\%$ Black only & 3.02 & - & - \\
$\%$ Latinx only & 14.88 & - & - \\
$\%$ Asian only & 4.55 & - & - \\
$\%$ International & 1.46 & - & - \\
$\%$ White & 73.96 & - & - \\
$\%$ Other (collapsed) & 2.13 & - & - \\
$\%$ Female & 50.54 & - & - \\
$\%$ Male & 49.46 & - & - \\
\% Transfer students & 24.50 & - & - \\
\hline
\end{tabular}

In Table 2, we use first-generation status, Pell-eligibility, ethnicity, gender, transfer status, total number of semesters, cumulative GPA, high school rank, high school class size, and converted SAT mathematics and critical reading scores, to predict the likelihood of graduating from any major and a STEM major for students who initially declare a STEM major. When looking at the model for students who initially declare a STEM major, but graduate in any major, we observe that first-generation students have a $1.3 \%$ less likely to graduate in any major. In relation to White students, Black and Asian students are less likely to graduate in any major, while females are about $2 \%$ more likely to graduate. Transfer students are also more likely to graduate, as are students completing more total semesters and having higher cumulative GPA. SAT scores for critical reading, though significant, are negligible. When looking at the model for students who graduate with a STEM degree, we find that Pell-eligible students are more likely to persist, as are all other ethnicities, compared to White students. However, female persistence falls by about $14.1 \%$ compared to their male counterparts, while additional semesters of school increase the likelihood slightly for all students. Having a higher cumulative GPA is associated with a decrease in the likelihood of being a STEM graduate. Though high school rank, high school class size, and SAT mathematics and critical reading scores are all significant, they are close to negligible. In summary, though students of color have a lower likelihood of graduating in any major, it seems they persist in STEM once they declare a STEM major at higher rates than their White counterparts, though the same cannot be said for females. 
Table 2. Multilevel logistic regression results expressed as odds ratios predicting graduation from any major and in a STEM major

\begin{tabular}{|c|c|c|}
\hline Variables & $\begin{array}{c}\text { Any major graduate } \\
\text { OR (SE) }\end{array}$ & $\begin{array}{c}\text { STEM graduate } \\
\text { OR (SE) }\end{array}$ \\
\hline \multirow[t]{2}{*}{ First-generation } & $0.987 * *$ & 0.983 \\
\hline & $(0.00434)$ & $(0.0104)$ \\
\hline \multirow[t]{2}{*}{ Pell-elligible } & 0.997 & $1.021^{*}$ \\
\hline & $(0.00437)$ & $(0.0103)$ \\
\hline \multicolumn{3}{|l|}{ Ethnicity [Ref. White] } \\
\hline \multirow[t]{2}{*}{ Black only } & $0.973 * * *$ & $1.062 * * *$ \\
\hline & $(0.00580)$ & $(0.0154)$ \\
\hline \multirow[t]{2}{*}{ Latinx only } & 1.006 & $1.063 * * *$ \\
\hline & $(0.00303)$ & $(0.00749)$ \\
\hline \multirow[t]{2}{*}{ Asian only } & $0.988^{*}$ & $1.214 * * *$ \\
\hline & $(0.00478)$ & $(0.0136)$ \\
\hline \multirow[t]{2}{*}{ International } & 0.984 & $1.288 * * *$ \\
\hline & $(0.0117)$ & $(0.0356)$ \\
\hline \multirow[t]{2}{*}{ Other (Collapsed) } & 0.988 & $1.100 * * *$ \\
\hline & $(0.00717)$ & $(0.0185)$ \\
\hline \multicolumn{3}{|l|}{ Gender } \\
\hline \multirow[t]{2}{*}{ Female } & $1.020 * * *$ & $0.859 * * *$ \\
\hline & $(0.00211)$ & $(0.00406)$ \\
\hline \multirow[t]{2}{*}{ Transfer Student } & $1.172 * * *$ & 0.991 \\
\hline & $(0.00337)$ & $(0.00659)$ \\
\hline \multirow[t]{2}{*}{ Total Number of Semesters } & $1.077 * * *$ & $1.002 *$ \\
\hline & $(0.000472)$ & $(0.00101)$ \\
\hline \multirow[t]{2}{*}{ Cumulative GPA } & $1.258 * * *$ & $0.948 * * *$ \\
\hline & $(0.00200)$ & $(0.00497)$ \\
\hline \multirow[t]{2}{*}{ High School Rank } & 1.000 & $0.999 * * *$ \\
\hline & $\left(1.64 \times 10^{-5}\right)$ & $\left(3.83 \times 10^{-5}\right)$ \\
\hline \multirow[t]{2}{*}{ High School Class Size } & 1.000 & $1.000 * * *$ \\
\hline & $\left(4.82 \times 10^{-6}\right)$ & $\left(1.11 \times 10^{-5}\right)$ \\
\hline \multirow[t]{2}{*}{ SAT (Mathematics) } & 1.000 & $1.000 * * *$ \\
\hline & $\left(1.19 \times 10^{-5}\right)$ & $\left(2.76 \times 10^{-5}\right)$ \\
\hline \multirow[t]{2}{*}{ SAT (Critical Reading) } & $1.000 * * *$ & $1.000 * * *$ \\
\hline & $\left(1.10 \times 10^{-5}\right)$ & $\left(2.54 \times 10^{-5}\right)$ \\
\hline Likelihood ratio test statistic & $12446.93 * * *$ & 2.02 \\
\hline Residual intraclass correlation & 0.4993 & 0.0002 \\
\hline Observations & 53,077 & 44,890 \\
\hline Number of cohorts & 11 & 11 \\
\hline
\end{tabular}

Note. ${ }^{* * *} p<0.001, * * p<0.01, * p<0.05$; SE in parenthesis. 
In order to gain a deeper look at the intersection of race, gender, and first-generation status, we used marginal effects to predict probabilities of graduating from any major (Table 3) and with a STEM degree (Table 4). Figure 1 shows the graph of the predicted probabilities. In every instance, females have a higher predicted probability of graduating in any major, regardless of first-generation status. Amongst first-generation males, White males have the highest probability of graduating in any major, while Black males have the lowest. Amongst non first-generation males, Latinx males are more likely to graduate, while Black males are the least likely. With first-generation and non first-generation females, Latinx females are the most likely to persist (whether first-generation or not), while Black females are the least likely. Overall, Black, first-generation males have the lowest probability, while Latinx non first-generation females have the highest.

Table 3. Multilevel logistic estimates of probability of graduating from any major, by ethnicity, gender, and first-generation status, 2003-2013

\begin{tabular}{lccc}
\hline Variable & Marginal Effect & Standard Error & Cell Size \\
\hline White, first-gen males & .8953794 & .0687831 & 535 \\
White, non first-gen males & .8827638 & .068915 & 20422 \\
White, first-gen females & .902493 & .068912 & 682 \\
White, non first-gen females & .9151086 & .0687846 & 20989 \\
Black, first-gen males & .8553413 & .0691119 & 147 \\
Black, non first-gen males & .8679568 & .0690208 & 635 \\
Black, first-gen females & .8750705 & .0691048 & 283 \\
Black, non first-gen females & .887686 & .069018 & 674 \\
Latinx, first-gen males & .8884182 & .0689136 & 986 \\
Latinx, non first-gen males & .9010337 & .0688293 & 3126 \\
Latinx, first-gen females & .9081473 & .0689099 & 1252 \\
Latinx, non first-gen females & .9207629 & .0688299 & 3214 \\
Asian, first-gen males & .8703455 & .0690458 & 174 \\
Asian, non first-gen males & .882961 & .0689324 & 1276 \\
Asian, first-gen females & .8900747 & .0690446 & 162 \\
Asian, non first-gen females & .9026902 & .0689356 & 1012 \\
International, first-gen males & .8664543 & .0698969 & 1 \\
International, non first-gen males & .8790698 & .0697621 & 59 \\
International, first-gen females & .8861835 & .0699032 & 591 \\
International, non first-gen females & .898799 & .0697727 & 0 \\
Other, first-gen males & .8707815 & .0692703 & 247 \\
Other, non first-gen males & .8833971 & .0691413 & 25 \\
Other, first-gen females & .8905107 & .069268 & 576 \\
Other, non first-gen females & .9031262 & .0691435 & 36 \\
\hline No, All matging & & 576 \\
\hline
\end{tabular}

Note. All marginal effects are statistically significant at the 1 percent level; probabilities for groups based on linear combinations of marginal effects from a saturated logistic model; cohort fixed effects are included in the model. 


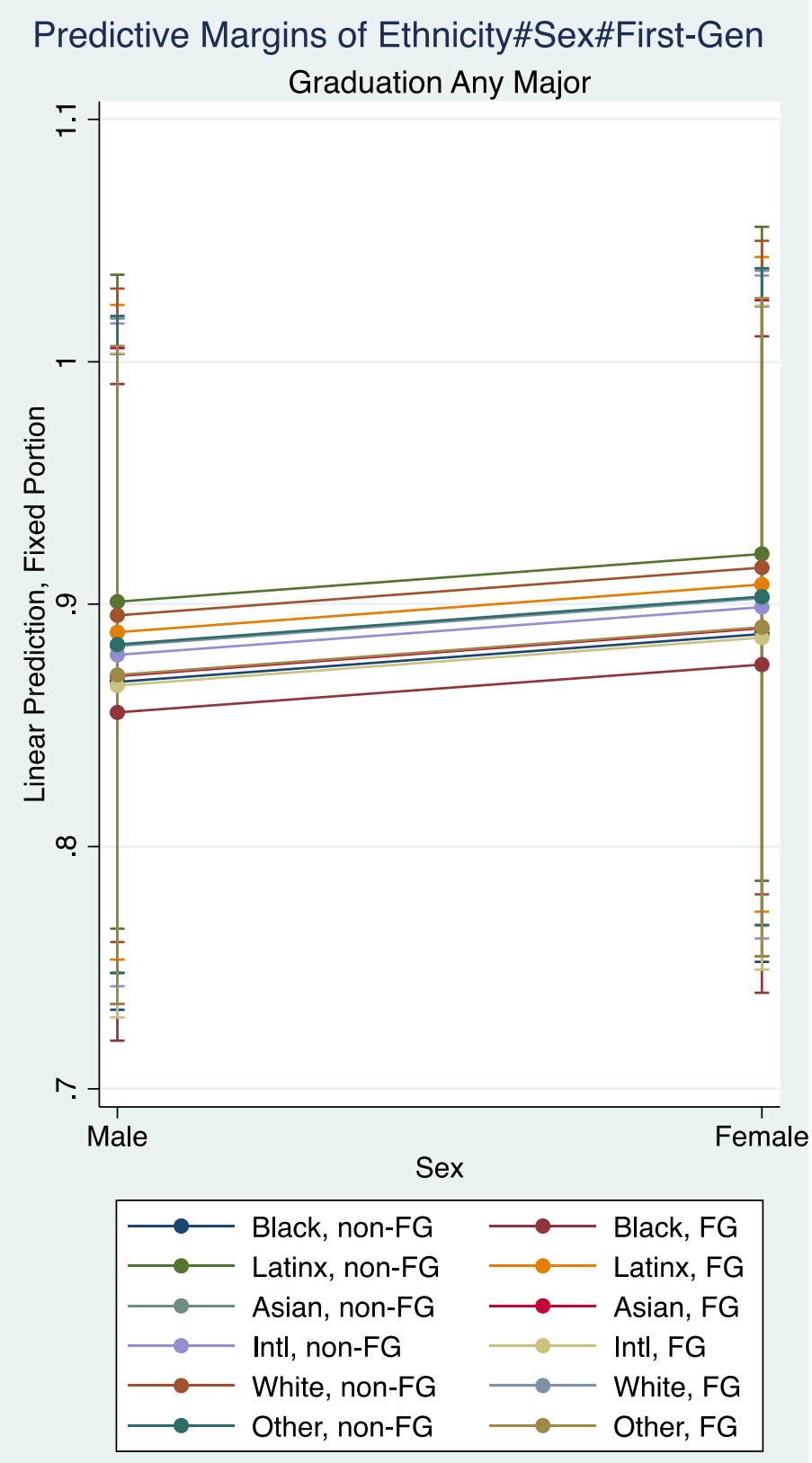

Figure 1. Predicted probabilities for intersection of race, gender, and first-generation status for graduation in any major.

Table 4 shows an insight at the intersection of ethnicity, gender, and first-generation status for graduating with a STEM degree, which is also displayed in Figure 2. In this case, we observe that in for every single group, females have a lowest probability of persisting in a STEM major. Amongst first-generation and non-first generation males and females, International and Asian students have the highest probability of persisting, while their White counterparts have the lowest. With respect to Black students, non first-generation students have higher probability of persisting, while first-generation females have the lowest. This is the same scenario for Latinx, Asian, and International students. Overall, White students seem to have the lowest probabilities for all their groups of persisting in STEM. 
Table 4. Multilevel logistic estimates of probability of graduating with a STEM degree, by ethnicity, gender, and first-generation status, 2003-2013

\begin{tabular}{lccc}
\hline Variable & Marginal Effect & Standard Error & Cell Size \\
\hline White, first-gen males & .6111433 & .0110724 & 535 \\
White, non first-gen males & .6279976 & .0041465 & 20422 \\
White, first-gen females & .4589453 & .0109026 & 682 \\
White, non first-gen females & .4757996 & .0040415 & 20989 \\
Black, first-gen males & .6717501 & .0170245 & 147 \\
Black, non first-gen males & .6886044 & .0146851 & 635 \\
Black, first-gen females & .5195521 & .0168246 & 283 \\
Black, non first-gen females & .5364064 & .0145519 & 674 \\
Latinx, first-gen males & .6719533 & .0110635 & 986 \\
Latinx, non first-gen males & .6888076 & .0073184 & 3126 \\
Latinx, first-gen females & .5197553 & .0108748 & 1252 \\
Latinx, non first-gen females & .5366096 & .0072312 & 3214 \\
Asian, first-gen males & .8050171 & .0147377 & 174 \\
Asian, non first-gen males & .8218714 & .0112853 & 1276 \\
Asian, first-gen females & .6528192 & .0146601 & 162 \\
Asian, non first-gen females & .6696734 & .0113114 & 1012 \\
International, first-gen males & .8642639 & .0294996 & 1 \\
International, non first-gen males & .8811181 & .0275963 & 591 \\
International, first-gen females & .7120659 & .0295625 & 0 \\
International, non first-gen females & .7289202 & .0277153 & .0196887 \\
Other, first-gen males & .7062592 & .016871 & 247 \\
Other, non first-gen males & .7231134 & .0196184 & 25 \\
Other, first-gen females & .5540612 & .0168742 & 576 \\
Other, non first-gen females & .5709155 & 36 \\
\hline Note. All & at & 596 \\
\hline
\end{tabular}

Note. All marginal effects are statistically significant at the 1 percent level; Probabilities for groups based on linear combinations of marginal effects from a saturated logistic model; Cohort fixed effects are included in the model. 


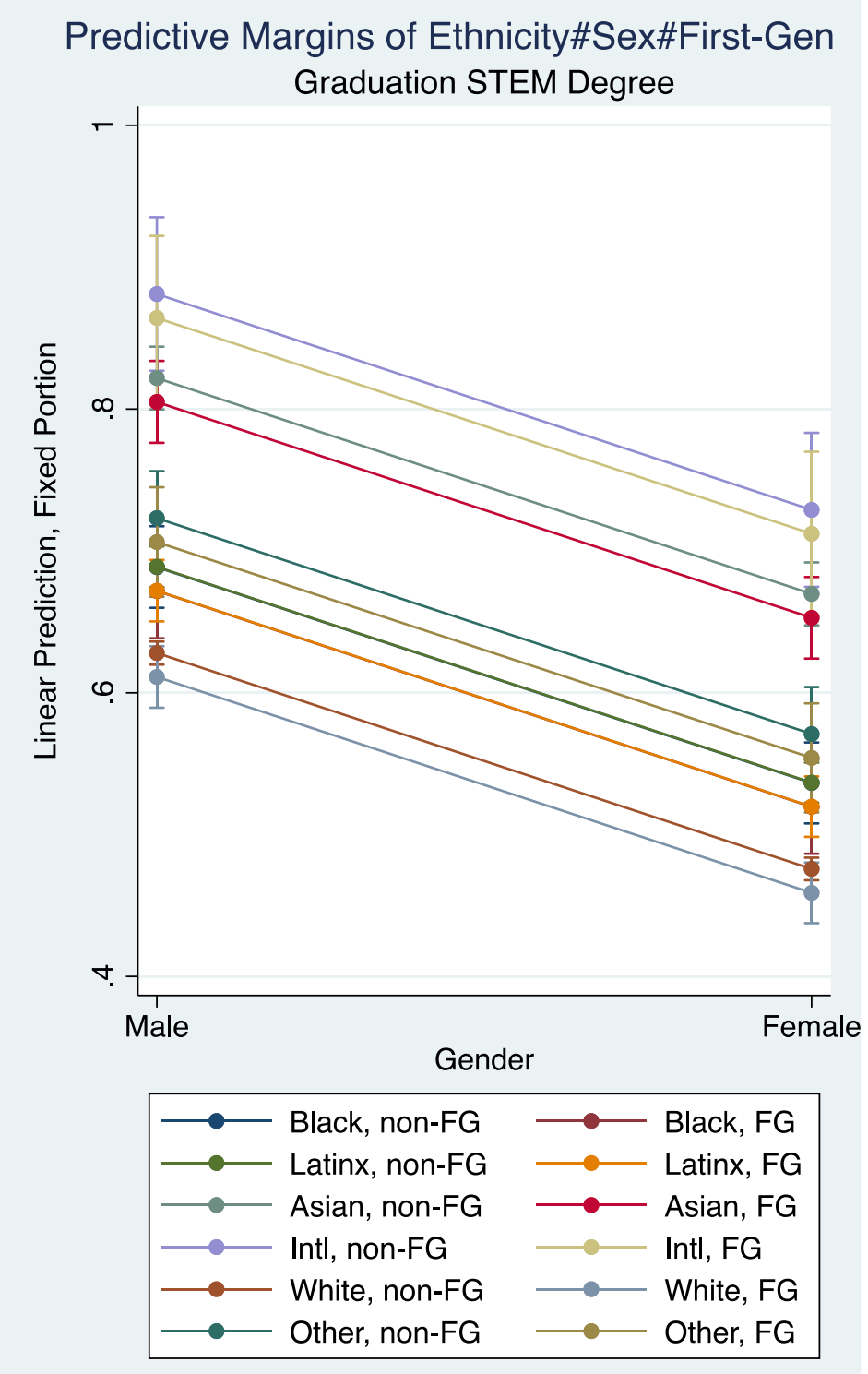

Figure 2. Predicted Probabilities for Intersection of Race, Gender, and First-Generation Status for Graduation with a STEM Degree.

\section{Discussion}

The results of this study highlight several important points. One of the biggest findings for our first research question reveal that, as with other institutions, particularly PWIs, disparities exist between Black and White students, even when holding all else equal (e.g., cumulative GPAs, high school rank, SAT scores). That is, Black students who initially declare a STEM major are less likely to graduate in any major. However, when they persist, they are more likely to graduate with a STEM degree than their White counterparts. Additionally, while females were more likely to graduate in any major, they are less likely to persist in STEM. These findings are not surprising given the review of literature.

The findings from the second research question reveal a much deeper look at the intersection of ethnicity, gender, and first-generation status. This is where we see this study's major contribution, as we provide a more nuanced analysis for this question. Our finding that Black, first-generation males have the lowest probability of persisting in any major is supported by research on Black male retention in higher education literature. However, our finding that Latinx, non first-generation females have the highest persistence was surprising considering that in a PWI, we would expect White females and/or males to persist at higher numbers than their peers of color as evident in the review of literature. There is plenty of research that addresses the needs for supports for Black males in general (e.g., Palmer \& Young, 2009; Roach, 2001; Strayhorn, 2013), but only few that address the needs of Black, first-generation males and females (e.g., 
Owens et al., 2010), especially in STEM. Additionally, our findings indicate that critical attention is needed to support Black females, as there is little research in this area (Smith, 2008). Future research should further explore if differences exist between Black students born in the US compared to Black foreign-born students. With regards to graduating with a STEM degree, our biggest finding was that White students are under-persisting as compared to their Black, Latinx, Asian, and International counterparts. It appears that in spite of the many systemic barriers non-White students have encountered at PWIs, they still persist in STEM. Therefore, more awareness is needed to draw attention to the persistence of non-White STEM students and their support systems. Another finding showed that first-generation females were the least likely to persist in STEM out of all Black students. As mentioned before, while much research focuses on Black males, we need to do more to support Black females, especially first-generation students. This could be attributed to the criminalization of Black females who are raised in underperforming schools with low socioeconomic status (Morris, 2018), which can follow students throughout their educational careers.

\subsection{Limitations and Recommendations for Future Research}

This study is limited by several things. First, though this study consists of a decade of rich, longitudinal data of all students who initially declared a STEM major, it is only of one large, research institution with a predominantly White population in the US Southwest, even if it is older data. Given that limitation, the findings are still important since demographics of those who graduate and eventually enter the STEM workforce continues to have limited diversity. Additionally, this university's STEM programs are considered some of the top by ranking entities and continues to recruit many international students every year.

Another limitation is the number of variables we were able to collect. Since the data collection was predetermined by the institution's internal data system, we were unable to recommend that other variables be collected. We recommend additional data be collected. For example, we used Pell-eligibility as a proxy for socioeconomic status, but a measure of income could potentially be a more robust indicator. As George-Jackson (2014) recommends, we should also have a cohesive definition of what STEM consists of as a field. Our study used definitions of STEM provided by the Department of Homeland Security (2016) and the National Science Foundation (2014). Therefore, because majors such as economics, sociology, and psychology, to name a few, were included in this study. While the reader may see this and think that our results potentially provide a skewed perception of STEM persistence at this university being that other studies have used more traditional STEM fields, we contend that is crucial that "traditional" STEM majors should be well-rounded in the humanities. That is, in line with QuantCrit, STEM majors should understand that what they are studying is not free of bias and their disciplines are rooted in White supremacist history (Noble, 2018; Strunk \& Hoover, 2019).

\subsection{Implications for Practitioners}

The results of this study are relevant to university admissions counselors, school advising staff, and professor hiring committees. Castellanos (2018) has pointed that faculty can have a significant positive effect in Latinas' decision to pursue STEM as a career choice. Therefore, hiring committees might consider recruiting more BIPOC STEM faculty. Moreover, this information serves admissions counselors and mentoring staff when working with high-achieving females and males.

This study also highlighted the extensive gap between Black students and either White or Asian and International students in their ability to persist. Many universities have begun to create initiatives for first-generation students' transition to university, such as the National Association of Student Personnel Administrators' (NASPA) Center for First-Generation Student Success, and their National First-Generation College Celebration on November 8, which encourages university and universities to support their first-generation students (NASPA, 2020). While these types of initiatives are for all university students, STEM university would benefit from expanding upon these events to create specific ones for their STEM majors who are students of color. Other initiatives that have shown to improve persistence for students of color are undergraduate research experiences (UREs; NASEM, 2017). A challenge to consider, however, is that particularly for PWIs, there may be an overrepresentation of White first-generation students taking advantage of these type of opportunities when minoritized students are underrepresented. Therefore, recruitment should be strategic and mindful (e.g., Schneider et al., 2015).

\section{Conclusion}

This study examined factors that predicted STEM persistence at a large, research university in the US Southwest. Some of our results aligned with the literature on racial and ethnic minorities and women in STEM. Unfortunately, our results also showed that at this particular university, Black and Latinx students are underrepresented, which is similar across programs in the US Guided by QuantCrit theory, we used multilevel models to determine factors that predicted 
persistence in any major and factors that predicted persistence in STEM, as well as used marginal effects to explore the intersection of ethnicity, gender, and first-generation status. Results highlighted the disparity that persist amongst Black students. We also highlighted the gap between first-generation White and Black first-generation females and their Asian and International counterparts with regards to persistence in STEM. As the focus on STEM pipeline production increases, there is not only increased pressure to find more students interested in pursuing these fields, but we must make larger, more concerted efforts at diversifying the field.

\section{References}

Burton, N. W., \& Ramist, L. (2001). Predicting success in college: SAT studies of classes graduating since 1980. New York: College Entrance Examination Board. Retrieved from https://files.eric.ed.gov/fulltext/ED562836.pdf

Castellanos, M. (2018). Examining Latinas' STEM career decision-making process: A psychosociocultural approach. The Journal of Higher Education, 89(4), 527-552. https://doi.org/10.1080/00221546.2018.1435133

College Board. (2016). Concordance tables. Retrieved from https://collegereadiness.collegeboard.org/educators/higher-ed/scoring/concordance

Crisp, G., \& Nora, A. (2010). Hispanic student success: Factors influencing the persistence and transfer decisions of Latino community college students enrolled in developmental education. Research in Higher Education, 51(2), 175-194. https://doi.org/10.1007/s11162-009-9151-x

Crisp, G., Nora, A., \& Taggart, A. (2009). Student characteristics, pre-college, college and environmental factors as predictors of majoring in and earning a STEM degree: An analysis of students attending a Hispanic serving institution. American Educational Research Journal, 46(4), 924-942. https://doi.org/10.3102/0002831209349460

Department of Homeland Security. (2016). STEM designated degree program list. Retrieved from https://www.ice.gov/sites/default/files/documents/Document/2016/stem-list.pdf

Everson, H. T., \& Millsap, R. E. (2004). Beyond individual differences: Exploring school effects on SAT scores. Educational Psychologist, 39(3), 157-172. https://doi.org/10.1207/s15326985ep3903_2

Espinosa, L. (2011) Pipelines and pathways: Women of color in undergraduate STEM majors and the college experiences that contribute to persistence. Harvard Educational Review, 81(2), 209-241. https://doi.org/10.17763/haer.81.2.92315ww157656k3u

Fleming, J. (2002). Who will succeed in college? When the SAT predicts Black students' performance. The Review of Higher Education, 25(3), 281-296. https://doi.org/10.1353/rhe.2002.0010

Fleming, J., \& Garcia, N. (1998). Are standardized tests fair to African Americans? The Journal of Higher Education, 69(5), 471-495. https://doi.org/10.1080/00221546.1998.11775147

Fleming, J., \& Morning, C. (1998). Correlates of the SAT in minority engineering students. The Journal of Higher Education, 69(1), 89-108. https://doi.org/10.1080/00221546.1998.11775126

Flynn, D. T. (2016). STEM field persistence: The impact of engagement on postsecondary STEM persistence for underrepresented minority students. Journal of Educational Issues, 2(1), 185-214. https://doi.org/10.5296/jei.v2i1.9245

Galla, B. M., Shulman, E. P., Plummer, B. D., Gardner, M., Hutt, S. J., Goyer, J. P., D’Mello, S. K., Finn, A. S., \& Duckworth, A. L. (2019). Why high school grades are better predictors of on-time college graduation than are admissions test scores: The roles of self-regulation and cognitive ability. American Educational Research Journal, 56(6), 2077-2115. https://doi.org/10.3102/0002831219843292

Garcia, N. M., \& Mayorga, O. J. (2018). The threat of unexamined secondary data: A critical race transformative convergent mixed methods. Race Ethnicity and Education, 21(2), 231-252. https://doi.org/10.1080/13613324.2017.1377415

Garriott, P. O., Navarro, R. L., \& Flores, L. Y. (2017). First-generation college students' persistence intentions in engineering majors. Journal of Career Assessment, 25(1), 93-106. https://doi.org/10.1177/1069072716657533

Gayles, J. G., \& Ampaw, F. (2014). The impact of college experiences on degree completion in STEM fields at four-year institutions: Does gender matter? The Journal of Higher Education, 85(4), 439-468. https://doi.org/10.1080/00221546.2014.11777336

George-Jackson, C. E. (2014). Undergraduate women's persistence in the sciences. NASPA Journal About Women in Higher Education, 7(1), 96-119. https://doi.org/10.1515/njawhe-2014-0006 
Gillborn, D., Warmington, P., \& Demack, S. (2018). QuantCrit: Education, policy, 'Big Data' and principles for a critical race theory of statistics. Race Ethnicity and Education, 21(2), 158-179. https://doi.org/10.1080/13613324.2017.1377417

Griffith, A. L. (2010). Persistence of women and minorities in STEM field majors: Is it the school that matters? Economics of Education Review, 29, 911-922. https://doi.org/10.1016/j.econedurev.2010.06.010

Guiffrida, D. A., \& Douthit, K. Z. (2010). The Black student experience at predominantly White colleges: Implications for school and college counselors. Journal of Counseling \& Development, 88, 311-318. https://doi.org/10.1002/j.1556-6678.2010.tb00027.x

Hurtado, S., Alvarado, A. R., \& Guillermo-Wann, C. (2015). Thinking about race: The salience of racial identity at two- and four-year colleges and the climate for diversity. The Journal of Higher Education, 86(1), 127-152. https://doi.org/10.1353/jhe.2015.0000

Hurtado, S., Cabrera, N. L., Lin, M. H., Arellano, L., \& Espinosa, L. L. (2009). Diversifying science: Underrepresented student experiences in structured research programs. Research in Higher Education, 50(2), 189-214. https://doi.org/10.1007/s11162-008-9114-7

Hurtado, S., Cuellar, M., \& Guillermo-Wann, C. (2011). Quantitative measures of students' sense of validation: Advancing the study of diverse learning environments. Enrollment Management Journal, 5(2), 53-71.

Johnson, D. R. (2012). Campus racial climate perceptions and overall sense of belonging among racially diverse women in STEM majors. Journal of College Student Development, 53(2), 336-346. https://doi.org/10.1353/csd.2012.0028

King, B. (2016). Does postsecondary persistence in STEM vary by gender? AERA Open, 2(4), 1-10. https://doi.org/10.1177/2332858416669709

Long, M. C., \& Tienda, M. (2010). Changes in Texas universities' applicant pools after the Hopwood decision. Social Science Research, 39, 48-66. https://doi.org/10.1016/j.ssresearch.2009.06.004

López, N., Erwin, C., Binder, M., \& Chavez, M. J. (2018). Making the invisible visible: Advancing quantitative methods in higher education using critical race theory and intersectionality. Race Ethnicity and Education, 21(2), 180-207. https://doi.org/10.1080/13613324.2017.1375185

Moffat, G. K. (1993). The validity of the SAT as a predictor of grade point av-erage for nontraditional college students. Paper presented at the annual meeting of the Eastern Educational Research Association, Clearwater Beach, FL. Retrieved from https://eric.ed.gov/?id=ED356252

Morris, M. W. (2018). Pushout: The criminalization of Black girls in schools. New York, NY: The New Press.

National Academies of Science, Engineering, and Medicine. (2017). Undergraduate research experiences for STEM students: Successes, challenges, and opportunities. Washington, DC: The National Academies Press. https://doi.org/10.17226/24622

National Academy of Sciences, National Academy of Engineering, and Institute of Medicine. (2007). Rising above the gathering storm: Energizing and employing America for a brighter economic future. Washington, DC: The National Academies Press.

National Academy of Sciences, National Academy of Engineering, and Institute of Medicine. (2010). Rising above the gathering storm, revisited: Rapidly approaching category 5. Washington, DC: The National Academies Press.

National Academy of Sciences, National Academy of Engineering, and Institute of Medicine. (2016). Barriers and opportunities for 2-year and 4-year STEM degrees: Systemic change to support diverse student pathways. Washington, DC: The National Academies Press. https://doi.org/10.17226/21739

National Association of Student Personnel Administrators. (2020). First-generation college celebration. Retrieved from https://firstgen.naspa.org/engagement/first-generation-college-celebration/first-generation-college-celebration

National Science Board. (2010). Preparing the next generation of STEM innovators: Identifying and developing our nation's human capital. Retrieved from http://www.nsf.gov/nsb/publications/2010/nsb1033.pdf

National Science Foundation, National Center for Science and Engineering Statistics. (2014). NSF approved STEM fields. Arlington, VA: National Science Foundation. Retrieved from https://www.btaa.org/docs/default-source/diversity/nsf-approved-fields-of-study.pdf?sfvrsn=1bc446f3_2 
National Science Foundation, National Center for Science and Engineering Statistics. (2017). Women, minorities, and persons with disabilities in science and engineering: 2017. Special report NSF 17-310. Arlington, VA: National Science Foundation. Retrieved from http://www.nsf.gov/statistics/wmpd/

Naumann, W. C., Bandalos, D., \& Gutkin, T. B. (2003). Identifying variables that predict college success for first-generation college students. Journal of College Admission, 181, 4-9.

Noble, S. U. (2018). Algorithms of oppression: How search engines reinforce racism. New York, NY: NYU Press. https://doi.org/10.2307/j.ctt1pwt9w5

Office of Congressional and Government Affairs. (2019). Achieving the promise of a diverse STEM workforce: Testimony of Mae Jemison to the $116^{\text {th }}$ Congress. https://www.nationalacademies.org/ocga/testimonies/116-session-1/mae-jemison/achieving-the-promise-of-a-di verse-stem-workforce

Owens, D., Lacey, K., Rawls, G., \& Holbert-Quince, J. A. (2010). First-generation African American male college students: Implications for career counselors. The Career Development Quarterly, 58(4), 291-300. https://doi.org/10.1002/j.2161-0045-2010.tb00179.x

Palmer, R. T., \& Young, E. M. (2009). Determined to succeed: Salient factors that foster academic success for academically unprepared Black males at a Black college. Journal of College Student Retention: Research, Theory \& Practice, 10(4), 465-482. https://doi.org/10.2190/CS.10.4.d

President's Council of Advisors on Science and Technology. (2012). Report to the President. Engage to excel: Producing one million additional college graduates with degrees in science, technology, engineering and mathematics.

Retrieved

from http://www.whitehouse.gov/sites/default/files/microsites/ostp/pcast-engage-to-excel-final_2-25-12.pdf

Reyes, M. (2011). Unique challenges for women of color in STEM transferring from community colleges to universities. Harvard Educational https://doi.org/10.17763/haer.81.2.324m5t1535026g76

Roach, R. (2001). Where are the Black men on campus? Black Issues in Higher Education, 18(6), 18-21.

Rothstein, J. M. (2004). College performance predictions and the SAT. Journal of Econometrics, 121(1-2), 297-317. https://doi.org/10.1016/j.jeconom.2003.10.003

Schneider, K. R., Bickel, A., \& Morrison-Shetlar, A. (2015). Planning and implementing a comprehensive student-centered research program for first-year STEM undergraduates. Journal of College Science Teaching, 44(3), 37-43. https://doi.org/10.2505/4/jcst15_044_03_37

Scott, T. P., Tolson, H., \& Huang, T. (2011). Predicting retention of mathematics and science majors. Journal of College Admission, 204, 20-24.

StataCorp. (2019). Stata Statistical Software: Release 16. College Station, TX: StataCorp, LLC.

Strunk, K. K., \& Hoover, P. D. (2019). Quantitative methods for social justice and equity: Theoretical and practical considerations. In Research methods for social justice and equity in education (pp. 191-201). Cham, Switzerland: Palgrave Macmillan. https://doi.org/10.1007/978-3-030-05900-2

Trenor, J. M., Yu, S. L., Waight, C. L., \& Zerda, K. S. (2008). Influences for selecting engineering: Insights on access to social capital from two case studies. Paper presented at the $38^{\text {th }}$ Annual Frontiers in Education Conference. Saratoga Springs, October 22-25. https://doi.org/10.1109/FIE.2008.4720259

US Bureau of Labor Statistics. (2020). Employment in STEM occupations. Retrieved from https://www.bls.gov/emp/tables/stem-employment.htm

Williams, J. C., Phillips, K. W., \& Hall, E. V. (2016). Tools for change: Boosting the retention of women in the STEM pipeline. Journal of Research in Gender Studies, 6(1), 11-75. https://doi.org/10.22381/JRGS6120161

Xu, Y. (2015). Focusing on women in STEM: A longitudinal examination of gender-based earning gap of college graduates. The Journal of Higher Education, 86(4), 489-523. https://doi.org/10.1080/00221546.2015.11777373

\section{Copyrights}

Copyright for this article is retained by the author(s), with first publication rights granted to the journal.

This is an open-access article distributed under the terms and conditions of the Creative Commons Attribution license (http://creativecommons.org/licenses/by/4.0/). 